\title{
Increase in somatostatin to glucagon ratio in islets of alloxan-diabetic dogs: effect of insulin-induced euglycemia
}

\author{
K.S. Rastogi, P.L. Brubaker, and A. Kawasaki \\ Department of Physiology, University of Toronto, Toronto, ON MSS IA8, Canada \\ S. EFENDIC \\ Karolinska Institute, Stockholm, Sweden
}

AND

M. VRANIC ${ }^{1}$

Department of Physiology and Department of Medicine, University of Toronto, Toronto, ON MSS 1A8, Canada

Received October 29, 1992

Rastogi, K.S., Brubaker, P.L., KaWasaki, A., Efendic, S., and VRanic, M. 1993. Increase in somatostatin to glucagon ratio in islets of alloxan-diabetic dogs: effect of insulin-induced euglycemia. Can. J. Physiol. Pharmacol. 71: 512-517.

We have previously shown that acute insulin-induced normalization of glycemia in alloxan-diabetic (A-D) dogs results in marked inhibition of total pancreatic glucagon content, but normalization of somatostatin content. We suggested that this glucagon deficiency might account for A-cell unresponsiveness in diabetes. To examine these changes in detail at the islet level, morphometric and immunologic analyses were carried out on pancreata from four normal (N), four hyperglycemic A-D dogs (HD), and four A-D dogs after acute normalization of glycemia with insulin (ND). The total number of islets per pancreas $\left(3.9 \times 10^{6} \pm 0.5 \times 10^{6}\right.$; determined from the number of islets per square millimetre) was reduced by $60 \%(p<$ 0.001 ) in HD, and this was not affected by acute normalization of glycemia. Insulin content per islet was $1247 \pm 205 \mathrm{pg}$ in N, and this was reduced in both HD and ND to 2 and 5\%, respectively ( $p<0.001$ ). Similarly, insulin-containing B-cell area was $76 \pm 1 \%$ of the total islet area in $\mathrm{N}$, and was unmeasurable in HD and ND. Glucagon content per islet was $89 \pm 6 \mathrm{pg}$ in $\mathrm{N}$, and this was increased by $215 \%(p<0.001)$ in HD, but was normalized in ND. The A-cell area increased concomitantly by $170 \%$ from $17 \pm 1$ to $46 \pm 2 \%(p<0.01)$ of islet area in HD, and remained elevated in ND. In contrast, somatostatin content per islet was $3.0 \pm 1.1 \mathrm{pg}$ in $\mathrm{N}$, but was increased by 567\% $(p<0.01)$ in HD and fell to $200 \%(p=$ $\mathrm{ns})$ of $\mathrm{N}$ in ND. D-cell area increased by 55\% in HD, from $11.5 \pm 0.8$ to $17.8 \pm 0.9 \%(p<0.01)$, and remained elevated at $15.6 \pm 1.1 \%(p<0.01)$ in ND. The ratio of somatostatin to glucagon content in the islet was therefore $0.03 \pm 0.01$ in $\mathrm{N}$, and this was increased by $167(p=\mathrm{ns})$ and $333 \%(p<0.05)$ in HD and ND, respectively. We speculate that the increase in the islet somatostatin to glucagon ratio in normoglycemic diabetic dogs may play a role in the suppression of glucagon responses in diabetes.

Key words: islet, glucagon, somatostatin, diabetes, insulin-induced euglycemia.

Rastogl, K.S., Brubaker, P.L., Kawasaki, A., Efendic, S., et Vranic, M. 1993. Increase in somatostatin to glucagon ratio in islets of alloxan-diabetic dogs: effect of insulin-induced euglycemia. Can. J. Physiol. Pharmacol. 71 : $512-517$.

Nous avons déjà montré que, chez des chiens rendus diabétiques par alloxane (D-A), une normalisation aiguë de la glycémie avec de l'insuline provoque une inhibition marquée de la teneur totale en glucagon pancréatique, mais normalise la teneur en somatostatine. Nous avons suggéré que cet déficit en glucagon pourrait expliquer l'insensibilité des cellules A lors de diabète. Pour examiner en détail ces variations au niveau des îlots pancréatiques, des analyses immunologiques et morphométriques ont été effectuées sur le pancréas de 4 chiens D-A hyperglycémiques (DH), de 4 chiens normaux $(\mathrm{N})$ et de 4 chiens D-A, après la normalisation aiguë de la glycémie avec de l'insuline (DN). Le nombre total d'îlots par pancréas $\left(3,9 \times 10^{6} \pm\right.$ $0,5 \times 10^{6}$; déterminé à partir du nombre total d'îlots par millimètre carré) a été réduit de $60 \%(p<0,001)$ chez les DH, et ceci n'a pas été influencé par la normalisation aiguë de la glycémie. La concentration d'insuline par îlot a été de $1247 \pm$ $205 \mathrm{pg}$ chez les $\mathrm{N}$, et a été réduite à 2 et $5 \%$, respectivement $(p<0,001)$, chez les DH et les DN. Similairement, la surface de cellules $\mathrm{B}$ contenant de l'insuline a été de $76 \pm 1 \%$ de la surface totale des îlots chez $\mathrm{N}$, et n'était pas mesurable chez les $\mathrm{DH}$ et les $\mathrm{DN}$. La concentration de glucagon par îlot a été de $89 \pm 6 \mathrm{pg}$ chez les $\mathrm{N}$; elle a été augmentée de $215 \%$ $(p<0,001)$ chez les DH, mais a été normalisée chez les DN. En même temps, la surface de cellules A a augmenté de $170 \%$, de $17 \pm 1$ à $46 \pm 2 \%$ de la superficie des îlots $(p<0,01)$ chez les DH, et est demeurée élevée chez les DN. À l'opposé, la teneur en somatostatine par îlot a été de 3,0 $\pm 1,1 \mathrm{pg}$ chez les $\mathrm{N}$, mais a été augmentée de $567 \%$ chez les $\mathrm{DH}(p<$ 0,01 ), et diminuée de $200 \%(p=n s)$ chez les DN par rapport aux $N$. La superficie de cellules D a augmenté de $55 \%$ chez les DH, de $11,5 \pm 0,8$ à 17,8 $\pm 0,9 \%(p<0,01)$, et est demeurée élevée à $15,6 \pm 1,1 \%(p<0,01)$ chez les DN. Le rapport de la concentration somatostatine à glucagon dans l'îlot a été de $0,03 \pm 0,01 \mathrm{chez}$ les $\mathrm{N}$, et a été augmenté de $167 \%$ ( $p=\mathrm{ns}$ ) et de $333 \%(p<0,05)$ chez les DH et les DN, respectivement. Nous supposons que l'augmentation du rapport somatostatine à glucagon dans les îlots des chiens diabétiques normoglycémiques pourrait jouer un rôle dans la suppression des réponses au glucagon chez les diabétiques.

Mots clés : îlot, glucagon, somatostatine, diabète, normoglycémie induite par insuline.

'Author for correspondence. 


\section{Introduction}

Some aspects of glucoregulation in diabetes are not well understood (Hilstead et al. 1981; Bolli et al. 1982; Lussier et al. 1986; Hetenyi et al. 1989). We have reported that glucose production does not increase appropriately during increased glucose utilization in alloxan-diabetic (A-D) dogs (Lussier et al. 1986; Hetenyi et al. 1989) because, as in insulin-dependent diabetes mellitus (Bolli et al. 1982), there is impairment of the glucagon response to insulin-induced hypoglycemia. This counterregulatory unresponsiveness has been attributed to impaired A-cell secretion of glucagon, independent of the presence of autonomic neuropathy (Hilstead et al. 1981). Loss of A-cell responsiveness to nutrients has also been demonstrated in diabetes (Unger and Orci 1977; Roberge and Brubaker 1991).

Recently, we have shown increased total pancreatic somatostatin content with no change in pancreatic glucagon content in A-D dogs despite a $70 \%$ reduction in the total number of islets per pancreas (Rastogi et al. 1990). Acute insulin-induced normalization of glycemia in these dogs resulted in a dramatic decrease in total pancreatic glucagon content to $20 \%$ of normal levels with concomitant reduction of total pancreatic somatostatin content to normal. We suggested that this marked fall in glucagon content relative to somatostatin might account, in part, for the impaired glucagon responsiveness in diabetes. In the present investigation, we have extended these studies to examine the changes in islet hormone content and hormone area per islet both in uncontrolled diabetes and following acute normalization of glycemia with insulin. A combination of immunologic hormone analysis with morphometric quantitation of the areas of immunocytochemically localized insulin-, glucagon-, and somatostatin-containing cells in islets now permits determination of whether the previously reported (Rastogi et al. 1990) changes in total pancreatic glucagon and somatostatin in diabetic dogs were due to changes in islet hormone area and (or) to alterations in islet hormone content. A preliminary report of these findings has been communicated in abstract form (Rastogi et al. 1991).

\section{Materials and methods}

\section{Animals}

The animals used in the present study have been described previously (Rastogi et al. 1990). In brief, healthy mongrel dogs weighing $18-23 \mathrm{~kg}$ were fed $200 \mathrm{~g}$ of dog chow containing $50 \%$ (w/w) carbohydrate (Ralston Purina Canada, Mississauga, Ont.) and $400 \mathrm{~g}$ beef chunks (Dr. Ballard, Toronto, Ont.), daily (Rastogi et al. 1987, 1990). Access to water was ad libitum. Diabetes was induced by intravenous injection of alloxan monohydrate $(60 \mathrm{mg} / \mathrm{kg}$; Sigma Chemical Co., St. Louis, Mo.), and the animals were maintained for 4-6 weeks on regular plus intermediate-acting (NPH) pork insulin (11-20 IU of each per day) (Eli Lilly, Indianapolis, Ind.). Porcine insulin was used as it has the same primary structure as canine insulin. The insulin dose was adjusted daily to maintain glycosuria below $1 \%$ in the urine collected over a $24-\mathrm{h}$ period. Diabetic animals were then divided into two groups. In the first group of dogs (hyperglycemic diabetic, $\mathrm{HD}, n=4$ ), insulin was discontinued $48 \mathrm{~h}$ before sacrifice. In the second group of dogs (normoglycemic diabetic, ND, $n=4$ ), insulin was continued until the morning of sacrifice, when an additional dose of regular insulin (4-7 IU) was given, as necessary, to maintain normoglycemia $(80-120 \mathrm{mg} / \mathrm{dL})$ for at least $4 \mathrm{~h}$. Four additional normal dogs $(\mathrm{N})$ served as controls. All animals were fasted overnight prior to sacrifice. Plasma glucose levels were $89 \pm 3$, $251 \pm 38(p<0.001)$, and $100 \pm 14 \mathrm{mg} / \mathrm{dL}$ in $\mathrm{N}, \mathrm{HD}$, and ND dogs, respectively, as reported previously (Rastogi et al. 1990).

\section{Sample collection}

Blood samples were collected into chilled tubes containing $10 \%(\mathrm{v} / \mathrm{v})$ Trasylol (FBA Pharmaceuticals, New York) - EDTA (10000 kIU/ $\mathrm{mL}-2.4 \mathrm{~g} / \mathrm{dL}$ ). Animals were then anesthetized by injection of pentobarbital, and the pancreas was removed, weighed, and divided into head (free uncinate process), body (attached to duodenum), and tail (free splenic end) portions. The volume of the whole pancreas and of each portion of pancreas was determined by immersion in a measuring cylinder containing $0.9 \%(\mathrm{w} / \mathrm{v})$ saline at $4^{\circ} \mathrm{C}$. Pieces from each region were fixed in $10 \%(\mathrm{w} / \mathrm{v})$ buffered Formalin, or in $2.5 \%$ $(\mathrm{w} / \mathrm{v})$ glutaraldehyde in phosphate buffer. The remaining sections were then weighed and rapidly frozen on dry ice and stored at $-70^{\circ} \mathrm{C}$ until extraction.

\section{Plasma and tissue analyses}

To determine islet and hormone-containing cell areas, fixed pancreatic segments were dehydrated by passage through a graded series of alcohols and were then embedded in paraffin. Serial paraffin sections ( $0.005 \mathrm{~mm}$ thick) of pancreas from $\mathrm{N}, \mathrm{HD}$, and $\mathrm{ND}$ animals were simultaneously stained for insulin, glucagon, or somatostatin, using the unlabelled antibody - enzyme (peroxidase - antiperoxidase) method of Sternberger (1979), and counterstained with hematoxylin. Specificity controls used were (i) normal rabbit serum, (ii) phosphate buffer instead of primary antiserum, and (iii) adsorption of undiluted primary antiserum with $0.1-1 \mu \mathrm{g} / \mathrm{mL}$ of corresponding antigen. Morphometric measurements of islet area and of immunostained total cell area were carried out by an image analysis system using a somatographic digital bit pad, as described previously (Rastogi et al. 1990). Briefly, the stained slide was placed in a projector and $1-\mathrm{mm}^{2}$ sections were projected at a magnification of 200 times and the outlines of all islets were drawn for 10 consecutive sections. Islets in each $1-\mathrm{mm}^{2}$ projection were selected for measurement of areas of hormone-stained cells by the same procedure, but at a magnification of 500 times. Islet and cell tracings were digitized using an image analysis system consisting of a somatographic digital bit pad connected to an Osborne microcomputer, which provided total islet and hormone area in micrometres squared and number of islets per square millimetre of pancreatic tissue. The area of each islet was measured twice. The error involved in the morphometric measurement was assessed by calculating the coefficient of variation of duplicate determinations of islet area $(\mathrm{CV}=0.79 \pm 0.47,0.86 \pm 0.44$, and $0.09 \pm$ $0.38 \%$ for N, HD, and ND, respectively; $n=100$ islets each).

As reported previously (Rastogi et al. 1990), hormones were extracted for radioimmunoassay from frozen pancreatic segments by homogenization in acid-ethanol, at $4^{\circ} \mathrm{C}$. Plasma somatostatin levels were determined by radioimmunoassay (Rastogi et al. 1987).

\section{Data analysis}

The total number of islets in the whole pancreas was determined as a function of the pancreas volume, the section volume, the number of islets per square millimetre of pancreatic tissue, and the islet diameter. In brief, the number of sections in the whole pancreas was calculated as the pancreatic volume divided by the section volume $\left(1 \mathrm{~mm}^{2} \times 0.005 \mathrm{~mm}\right)$. Thus, the total number of islets in the whole pancreas $=$ the number of sections in the whole pancreas $\times$ the number of islets counted per section $\times$ correction factor (section thickness $(0.005 \mathrm{~mm})$ divided by islet diameter as determined from mean islet area). This correction factor was necessary to eliminate repeated counting of the same islet as a result of section thickness $(0.005 \mathrm{~mm})$ with respect to islet diameter $(0.059-0.068 \mathrm{~mm})$. Insulin, glucagon, and somatostatin content per islet were determined by dividing the total pancreatic content of hormone by the total number of islets in the pancreas. Glucagon content and area were obtained only from the body and tail regions, since glucagon could not be detected in the head region. Data are shown as mean \pm SEM. Statistical analysis was done by Student's $t$-test or ANOVA using the Statistical Analysis System package for personal computers (SAS Institute, Cary, N.C.). When the sample size differed by more than twofold, an unpaired Student's $t$-test was performed to ensure that variances were not different. 
TABLE 1. Morphometric analysis of percentage distribution of hormone area per islet in head, body, and tail regions of $4 \mathrm{~N}, 4 \mathrm{HD}$, and $4 \mathrm{ND}$ dog pancreata

\begin{tabular}{|c|c|c|c|c|c|c|c|c|c|}
\hline & \multicolumn{3}{|c|}{ Insulin } & \multicolumn{3}{|c|}{ Glucagon $^{a}$} & \multicolumn{3}{|c|}{ Somatostatin } \\
\hline & Head & Body & Tail & Head & Body & Tail & Head & Body & Tail \\
\hline $\mathbf{N}$ & $\begin{array}{c}75 \pm 1 \\
(45)\end{array}$ & $\begin{array}{c}75 \pm 1 \\
(45)\end{array}$ & $\begin{array}{c}77 \pm 1 \\
(34)\end{array}$ & $\begin{array}{l}\text { nd } \\
\text { nd }\end{array}$ & $\begin{array}{c}15 \pm 1 \\
(60)\end{array}$ & $\begin{array}{c}20 \pm 2 \\
(39)\end{array}$ & $\begin{array}{c}15 \pm 2 \\
(72)\end{array}$ & $\begin{array}{l}9 \pm 1 \\
(75)\end{array}$ & $\begin{array}{c}10 \pm 1 \\
(60)\end{array}$ \\
\hline HD & nd & nd & nd & nd & $\begin{array}{c}43 \pm 2 * * \\
(38)\end{array}$ & $\begin{array}{c}49 \pm 3^{* * *} \\
(43)\end{array}$ & $\begin{array}{c}25 \pm 3 * * \\
(45)\end{array}$ & $\begin{array}{c}20 \pm 2 * * \\
(70)\end{array}$ & $\begin{array}{l}14 \pm 1 * * \\
(128)\end{array}$ \\
\hline ND & nd & nd & nd & nd & $\begin{array}{l}52 \pm 3^{* *} \\
(78)\end{array}$ & $\begin{array}{c}43 \pm 3^{* *} \\
(62)\end{array}$ & $\begin{array}{c}18 \pm 3^{* *} \\
(44)\end{array}$ & $\begin{array}{c}17 \pm 2 * * \\
(90)\end{array}$ & $\begin{array}{c}12 \pm 1 \\
(58)\end{array}$ \\
\hline
\end{tabular}

NoTE: Values presented are mean \pm SEM. Values in parentheses indicate total number of islets measured in each region. nd, not detectable.

${ }^{a}$ The data for glucagon areas in $\mathrm{N}$ and HD have been reported previously (Rastogi et al. 1990).

**p $<0.01$ vs. normal values.

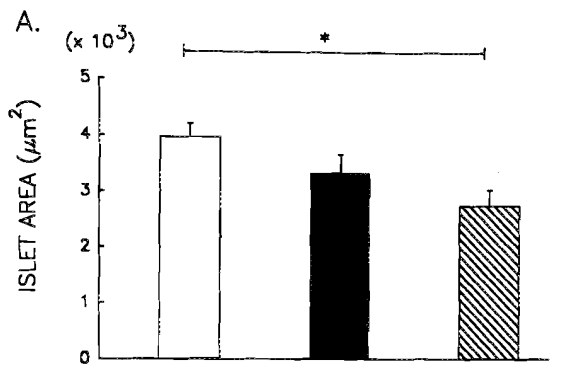

B.

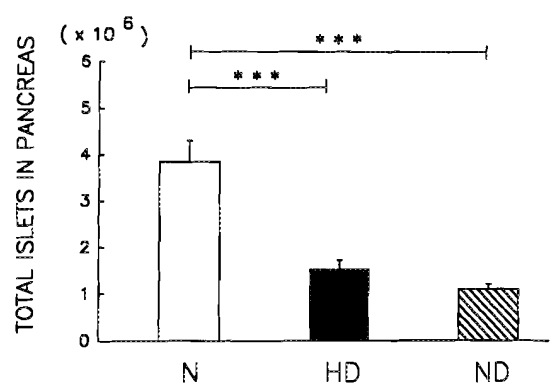

FIG. 1. (A) Morphometric analysis of islet area in body and tail region of pancreas of $4 \mathrm{~N}$ (open bars), $4 \mathrm{HD}$ (closed bars), and $4 \mathrm{ND}$ (hatched bars) dogs. The total number of $1-\mathrm{mm}^{2}$ sections measured in each condition was 149 for N, 64 for HD, and 94 for ND. (B) Total number of islets in the whole pancreas from $4 \mathrm{~N}, 4 \mathrm{HD}$, and $4 \mathrm{ND}$ dogs. ${ }^{*} p<0.05 ; * * * p<0.001$.

\section{Results}

The mean islet area in the pancreas of normal dogs was $3977 \pm 243 \mu^{2}$, and the total number of islets in the pancreas was $3.85 \times 10^{6} \pm 0.46 \times 10^{6}$ (Fig. 1). In HD dogs, the average area of each islet was not different from that of normal animals $\left(3339 \pm 331 \mu \mathrm{m}^{2}\right)$; however, the total number of islets was markedly diminished, to $1.54 \times 10^{6} \pm$ $0.19 \times 10^{6}(p<0.001)$. The islet size decreased significantly in ND dogs by $31 \%$ (to $2752 \pm 285 \mu \mathrm{m}^{2}$ ) when compared with normal controls $(p<0.05)$. As expected, islet number $\left(1.11 \times 10^{6} \pm 0.11 \times 10^{6}\right)$ did not change following acute normalization of glycemia, as compared with HD dogs.

Morphometric analysis of immunocytochemically localized insulin in pancreas from $\mathrm{N}$ dogs showed that the B-cell area comprised $76 \pm 1 \%$ of the total islet area (Fig. 2), and that this was not different between the head, body, and tail sections

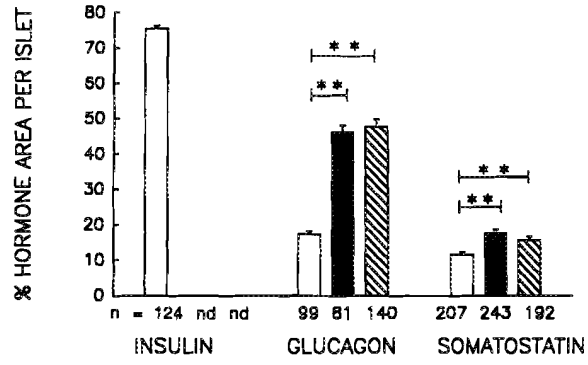

FIG. 2. Morphometric analysis of insulin, glucagon, and somatostatin areas as a percent of total islet area in whole pancreas from $4 \mathrm{~N}$ (open bars), 4 HD (closed bars), and 4 ND (hatched bars) dogs. The glucagon data are averaged for body and tail sections, and do not include the head region. $n$, total number of islets measured in each condition; nd, no detectable hormone in islets. ${ }^{* *} p<0.01$.
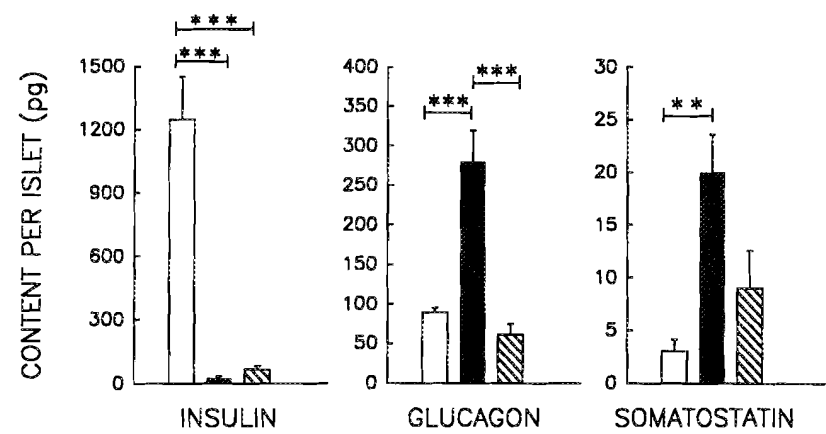

FIg. 3. Insulin, glucagon, and somatostatin content per islet in the whole pancreas from $4 \mathrm{~N}$ (open bars), $4 \mathrm{HD}$ (closed bars), and $4 \mathrm{ND}$ (hatched bars) dogs. The glucagon data are averaged for body and tail sections, and do not include the head region. ${ }^{* * p}<0.01 ;{ }^{* * *} p<$ 0.001 .

of the pancreas (Table 1). In HD and ND pancreas, only one or two insulin-containing cells were detectable, and thus the B-cell area as a percent of the islet area could not be quantitatively measured. Consistent with these immunohistochemical findings, the average insulin content per islet was found to be decreased from $1247 \pm 205 \mathrm{pg}$ in the $\mathrm{N}$ dog, to $24 \pm 11 \mathrm{pg}$ $(p<0.001)$ in $\mathrm{HD}$ and $66 \pm 17 \mathrm{pg}$ in ND $(p<0.001)$ (Fig. 3).

Glucagon cell area was similar in the body and tail regions of the pancreas, with undetectable glucagon in islets of the 


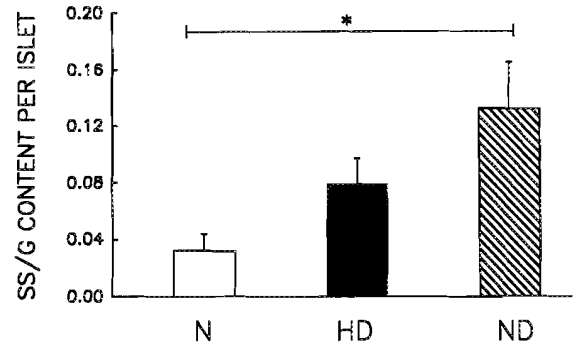

FIG. 4. Ratio of somatostatin to glucagon content per islet in $4 \mathrm{~N}$ (open bar), $4 \mathrm{HD}$ (closed bar), and $4 \mathrm{ND}$ (hatched bar) dogs. $* p<0.05$.

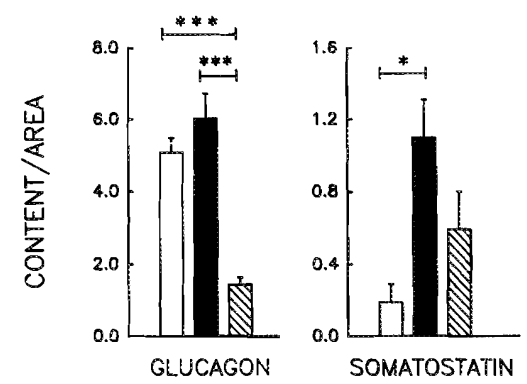

FIG. 5. Islet content of glucagon and somatostatin (pg) per percent of total A- and D-cell area per islet, respectively, for $4 \mathrm{~N}$ (open bars), $4 \mathrm{HD}$ (closed bars), and $4 \mathrm{ND}$ (hatched bars) dogs. ${ }^{*} p<0.05$; ${ }^{* * *} p<0.001$.

head region (Table 1). Glucagon cell area in body and tail increased by $170 \%$ in islets of hyperglycemic diabetic pancreas, from $17 \pm 1$ to $46 \pm 2 \%(p<0.01)$ (Fig. 2, Table 1), and this was paralleled by a $215 \%$ increase in the glucagon content of the islets (from $89 \pm 6$ to $280 \pm 40 \mathrm{pg}$, $p<0.001$ ) (Fig. 3). Normalization of glycemia did not alter the A-cell area $(48 \pm 2 \%)$ from that found in HD pancreas; however, the glucagon content of the islet was normalized (to $61 \pm 13 \mathrm{pg}$ ), indicating degranulation of A-cells.

Analysis of the somatostatin-containing D-cell area in islets showed that somatostatin area was $11.5 \pm 0.8 \%$ of the total islet area (Fig. 2), and did not vary significantly between regions of the pancreas (Table 1 ). In HD dogs, the islet D-cell area increased significantly, by $55 \%(p<0.01)$. Normalization of glycemia did not alter the somatostatin-containing islet area. The somatostatin content of the islet increased by $567 \%$ in $\mathrm{HD}$ dogs (from $3.0 \pm 1.0$ to $20.0 \pm 3.6 \mathrm{pg}, p<0.01$ ), and establishment of euglycemia decreased islet somatostatin content to $9.0 \pm 3.6 \mathrm{pg}$ (Fig. 3).

Figure 4 illustrates the ratio of somatostatin to glucagon content per islet. The ratio increased by $132 \%$ in HD dogs (from $0.03 \pm 0.01$ to $0.08 \pm 0.02$ ); however, this did not reach statistical significance. Insulin regimen to normalize blood glucose resulted in a further increase in this ratio (to $0.13 \pm 0.03)(p<0.05)$. A similar trend was seen when the somatostatin to glucagon ratio was calculated on the basis of total hormonal content of the different regions of pancreas, as reported earlier (Rastogi et al. 1990). Glucagon and somatostatin content per percent of total A- and D-cell area per islet, respectively, are shown in Fig. 5. There was a significant decrease in glucagon content per A-cell area in ND $(p<$ 0.001 ), when compared with $\mathrm{N}$ and $\mathrm{HD}$ dogs. In contrast, somatostatin content per D-cell area increased in HD $(p<$
0.05 ) and, after normalization of glycemia, decreased to a level that was intermediate between that found in $\mathrm{N}$ and HD dogs.

Plasma somatostatin in normal fasting dogs was $25 \pm 2 \mathrm{pg}$ and increased by $68 \%$ in HD dogs, to $42 \pm 4 \mathrm{pg}(p<0.01)$. Plasma somatostatin values returned to normal $(27 \pm 6)$ after normalization of glucose with insulin treatment. As reported previously (Rastogi et al. 1990), plasma insulin was reduced (from $12 \pm 1$ to $7 \pm 1 \mu \mathrm{U} / \mathrm{mL}, p<0.05$ ) and glucagon was increased (from $128 \pm 29$ to $304 \pm 90 \mathrm{pg} / \mathrm{mL}, p<0.05$ ) in $\mathrm{HD}$ dogs, and these values were normalized (to $12 \pm 3 \mu \mathrm{U} / \mathrm{mL}$ and $214 \pm 41 \mathrm{pg} / \mathrm{mL}$, respectively) with insulin treatment.

\section{Discussion}

In the present study, we have examined changes in total islet hormone area in response to metabolic perturbations. We have observed a direct relationship between total hormone area and hormone content, in islets from normal and hyperglycemic diabetic dogs. Interestingly, a dissociation between hormone area and hormone content was noted in islets from dogs in which acute normoglycemia was achieved by insulin administration. Thus, although total islet hormone area did not decrease in acutely normoglycemic dogs, islet hormone content was normalized either totally (as in the case of glucagon) or partially (as for somatostatin). This decrease in hormone content cannot be directly accounted for by an increase in release of either glucagon or somatostatin, as restoration of euglycemia was associated with normalization of the plasma levels of these hormones. Our findings therefore imply that, in diabetes, there are acute effects of insulin and (or) of normalization of glycemia on the A- and D-cells, to reduce hormone content.

Islet size and the number of islets per square millimetre of pancreatic tissue in dogs were in close agreement with those observed in rats and humans (Parsons et al. 1983; Soejima and Landing 1986). In the present study, we were also able to calculate the total number of islets in the whole pancreas. It was interesting to note that, in addition to a $60 \%$ decrease in the total number of islets per pancreas, there was a $31 \%$ decrease in islet area in pancreas of ND, which was less apparent in HD dogs. The reason for the difference in islet area between HD and ND dogs is not clear. We speculate that, in diabetes, there is a reduction of mean islet area that is masked under hyperglycemic conditions possibly as a result of osmolarityinduced volume expansion. It should also be noted that, despite the increase in total A- and D-cell area in diabetes, these two cell types only accounted for $60 \%$ of the total islet area in HD and ND pancreas. It remains to be established how much of the remaining islet cell area can be accounted for by unstained B-cells, and how much by undifferentiated cells.

Within islets of normal dogs, insulin-containing B-cell area was $76 \%$ of the islet area, consistent with data from rats and mice (Orci et al. 1976; Beaton et al. 1978; Patel et al. 1978; Parsons et al. 1983; Ruggere and Patel 1984), monkeys (Jones et al. 1980), and humans (Orci et al. 1976; Stefan et al. 1982; Soejima and Landing 1986). In islets of hyperglycemic diabetic dogs, there was an almost total absence of immunologically detectable insulin-containing B-cells and a decrease in islet hormonal content to $2 \%$ of control. As there was a concomitant loss of total islet number in the pancreas of HD dogs to $40 \%$ of normal, it appears that alloxan treatment resulted not only in destruction of the B-cells but also of whole islets. 
Similarly, in streptozotocin-diabetic rats, reductions in the total number of islets (Chen et al. 1989), as well as in both the insulin content and the levels of proinsulin mRNA transcripts have been reported (Patel et al. 1978; Brubaker et al. 1989; Chen et al. 1989).

We have previously shown that total pancreatic glucagon content does not change in HD dogs (Rastogi et al. 1990). Similar findings have been reported for both glucagon (Patel et al. 1978; Brubaker et al. 1989) and proglucagon mRNA transcript (Brubaker et al. 1989) levels in the hyperglycemic, streptozotocin-diabetic rat. In the present study, however, glucagon content per islet was found to increase by $215 \%$ in HD. Our finding of a concomitant $60 \%$ decrease in islet number could therefore explain the apparent lack of change of total glucagon in the whole pancreas in diabetes (Patel et al. 1978; Stefan et al. 1982; Brubaker et al. 1989; Rastogi et al. 1990). Furthermore, morphometric analysis indicated that A-cell area per islet also increased by $170 \%$ in diabetic dogs. This indicates that the increased amount of glucagon per islet in HD was due to hyperplasia of A-cells rather than to an increased content of glucagon per A-cell. Interestingly, the glucagon content in each residual islet was acutely normalized by insulin-induced normoglycemia. This finding together with the $60 \%$ decrease in islet number probably contributed to a sharp fall in total pancreatic glucagon content in ND reported previously (Rastogi et al. 1990). As the total A-cell area remained high in $\mathrm{ND}$, these results suggest that glucagon content per A-cell was markedly diminished. The mechanism underlying such changes is not known, but may include inhibition of hormone gene expression and (or) increased turnover of hormone within the islet cell. In islets of diabetic rats, elevated levels of proglucagon mRNA transcripts were found to be reduced within $1 \mathrm{~h}$ of insulin treatment to normalize glycemia, suggesting that insulin regulates proglucagon gene expression in vivo or is required for its regulation by glucose (Chen et al. 1989). Direct inhibitory effects of insulin on proglucagon gene transcription have been reported for a glucagonproducing tumour cell line (Philippe 1989). Alternatively, changes in the metabolic state of the animal upon insulin treatment, such as decreased plasma levels of glucose, amino acids, and (or) fatty acids, may also have contributed to the decrease in glucagon content of ND dogs. This inhibition of glucagon production at the cellular level may account, in part, for the impaired glucagon responses to insulin-induced hypoglycemia (Hilstead et al. 1981; Bolli et al. 1982; Lussier et al. 1986; Hetenyi et al. 1989) and nutrients (Unger and Orci 1977; Roberge and Brubaker 1991) observed in diabetes.

A threefold increase in total pancreatic somatostatin content was previously observed by us in the HD dog, which was returned to normal with insulin treatment (Rastogi et al. 1990). In the present examination of these changes at the islet level, we found that somatostatin content per islet increased by $567 \%$ in HD and was at $200 \%$ of control in ND, whereas D-cell area was increased by only 55\% in both the HD and ND dog. This indicates the possibility of hyperplasia of the D-cell in diabetes, as well as increased somatostatin content per cell in HD and ND islets. Thus, the short-term normalization of glycemia did not reduce the elevated somatostatin levels per islet to normal. In streptozotocin-diabetic rats and monkeys, and in insulin-dependent diabetes mellitus, increased numbers of A- and D-cells have been observed with corresponding changes in plasma levels (Orci et al. 1976; Patel et al. 1978; Jones et al. 1980). Higher basal somatostatin levels have also been observed in alloxan-diabetic dogs (Schusdziara et al. 1977, 1978), in agreement with our findings. Recently, increased pancreatic somatostatin content and secretion were found to parallel changes in prosomatostatin mRNA transcript levels in rats (Papachristou et al. 1989). As glucagon and insulin are known to stimulate and inhibit the D-cell, respectively (Orci et al. 1976; Patel et al. 1978; Jones et al. 1980; Papachristou et al. 1989), it could be speculated that the high glucagon and (or) low insulin levels observed in HD may be directly responsible for increased somatostatin production in vivo. Increases in somatostatin content and D-cell hypertrophy and hyperplasia in diabetes could also be due to changes in glucose, free fatty acids, or ketones, which are known to increase pancreatic somatostatin release in the diabetic rat (Grill and Efendic 1984; Klaff and Taborsky 1987). Furthermore, the decrease in somatostatin content per islet in ND may be due to direct action of insulin on the D-cell, as insulin has been reported to inhibit prosomatostatin mRNA transcript levels in vivo in the pancreas of insulinopenic diabetic rats (Papachristou et al. 1989). Alternatively, the decrease in somatostatin may have been due to loss of stimulation by glucagon, as a consequence of the insulin-induced decrease in glucagon (Gerich et al. 1975; Kawamori et al. 1980; Hermansen et al. 1985; Gutniak et al. 1987; Papachristou et al. 1989).

Interestingly, we found that the acute normalization of glycemia with insulin decreased glucagon content per A-cell area to a greater extent than somatostatin per D-cell area, suggesting either a greater sensitivity of the A-cell to insulin, or inhibition of the A-cell by another factor, such as somatostatin. Somatostatin receptors have been found on A-cells (van Schravendijk et al. 1985), and the A-cell has been reported to be exquisitely sensitive to inhibition by somatostatin (Pipeleers et al. 1985). Thus, normalization of glycemia in diabetes is associated with inhibition of the A-cell possibly as a result of the effects of insulin and (or) somatostatin. The net result is an increased ratio of somatostatin to glucagon in the pancreatic islet. In conclusion, therefore, the ratio of somatostatin to glucagon in pancreatic islets was markedly increased by normalization of glycemia in diabetic dogs. This relative increase of somatostatin over glucagon per islet could, in part, contribute to the impaired glucagon responses to insulininduced lowering of plasma glucose often observed in diabetes.

\section{Acknowledgments}

The authors are grateful to D. Bilinski, M. Van Delangeryt, and L. Lam for excellent technical assistance and to Dr. Y.C. Patel for the antisomatostatin antiserum used for immunohistochemistry. The support of the Medical Research Council of Canada and of the Canadian Diabetes Association is gratefully acknowledged.

Beaton, D., Stefan, Y., Ravazzola, M., Malaisse-Lagae, F., Coleman, D.L., and Orci, L. 1978. Alteration of islet cell populations in spontaneously diabetic mice. Diabetes, 27: 1-7.

Bolli, G., De Feo, P., Campagnucci, P., Cortechini, M.G., Angeletti, G., Santeusanio, P., and Brunetti, P. 1982. Important role of adrenergic mechanisms in acute glucose counterregulation following insulin-induced hypoglycemia in type I diabetes: evidence for an effect mediated by beta-adrenoreceptors. Diabetes, 31: $641-647$.

Brubaker, P.L., So, D.C.Y., and Drucker, D.J. 1989. Tissuespecific differences in the levels of proglucagon-derived peptides in streptozotocin-induced diabetes. Endocrinology (Baltimore), 124: $3003-3009$. 
Chen, E., Komiya, I., Inman, L., McCorkle, K., Alan, T., and Unger, R.H. 1989. Metabolic and cellular responses of islets during perturbations of glucose homeostasis determined by in situ hybridization histochemistry. Proc. Natl. Acad. Sci. U.S.A. 86: 1367-1371.

Gerich, J.E., Tsalikan, E., and Lorenzi, M. 1975. Normalization of fasting hyperglucagonemia and excessive glucagon response to intravenous arginine in human diabetes mellitus by prolonged infusion of insulin. J. Clin. Endocrinol. Metab. 41: 1178-1180.

Grill, V., and Efendic, S. 1984. Abnormal D cell secretion in alloxan diabetes: influence by drug and aberrant metabolism. Am. J. Physiol. 246: E483-E492.

Gutniak, M., Grill, M., Wiechel, K.L., and Efendic, S. 1987. Basal and meal induced somatostatin-like immunoreactivity in healthy subjects and in IDDM and totally pancreatectomized patients. Effect of acute blood glucose normalization. Diabetes, 36: 802807.

Hermansen, K., Schmitz, O., and Orskov, H. 1985. Reversal of D and A cell insensitivity to glucose in alloxan diabetic dogs by treatment with artificial B cell (Biostator). Diabetes, 34: 260-266.

Hetenyi, G., Jr., Gauthier, C., Byers, M., and Vranic, M. 1989. Phlorizin induced normoglycemia partially restores glucoregulation in diabetic dogs. Am. J. Physiol. 256: E277-E283.

Hilstead, J., Madsbad, S., Kranup, T., Sestoft, L., Christensen, N.J., Tronier, B., and Galbo, M. 1981. Hormonal, metabolic and cardiovascular responses to hypoglycemia in diabetic autonomic neuropathy. Diabetes, 30: 626-633.

Jones, C.W., Reynolds, W.A., and Hoganson, G.E. 1980. Streptozotocin diabetes in the monkey. Plasma levels of glucose, insulin, glucagon and somatostatin with corresponding morphometric analysis of endocrine cells. Diabetes, 29: 536-546.

Kawamori, R., Schiri, M., and Kikuchi, M. 1980. Perfect normalization of excessive glucagon responses to intravenous arginine in human diabetes mellitus with artificial B cell. Diabetes, 29: $762-$ 765.

Klaff, L.J., and Taborsky, G.J., Jr. 1987. Pancreatic somatostatin is a mediator of glucagon inhibition by hyperglycemia. Diabetes, 36: 592-596.

Lussier, B., Vranic, M., Kovacevic, N., and Hetenyi, G., Jr. 1986. Glucoregulation in alloxan diabetic dogs. Metab. Clin. Exp. 35: $18-24$

Orci, L., Baetens, D., Rufener, C., Amherdt, M., Ravazzola, M., Studer, P., Malaisse-Lage, F., and Unger, R.H. 1976. Hypertrophy and hyperplasia of somatostatin containing D-cells in diabetes. Proc. Natl. Acad. Sci. U.S.A. 73: 1338-1342.

Papachristou, D.N., Pham, K., Zing, H.H., and Patel, Y.C. 1989. Tissue specific alterations in somatostatin mRNA accumulation in streptozotocin-induced diabetes. Diabetes, 38: 752-757.

Parsons, J.A., Hartfel, M.A., Hegre, D.D., and McEvaoy, R.C. 1983. Effect of MTTW15 mammosomatotrophic tumours on pancreatic islet hormones. Diabetes, 32: 67-74.

Patel, Y.C., Cameron, D.P., and Bankier, A. 1978. Changes in somatostatin concentration in pancreas and other tissues of strep- tozotocin diabetic rats. Endocrinology (Baltimore), 103: 917923.

Philippe, J. 1989. Glucagon gene transcription is negatively regulated by insulin in a hamster islet cell line. J. Clin. Invest. 84: 672-677.

Pipeleers, D.G., Schuil, F.C., van Schravendijk, C.F.H., and van de Winkel, M. 1985. Interplay of nutrients and hormones in the regulation of glucagon release. Endocrinology (Baltimore), 117: $817-823$.

Rastogi, K.S., Efendic, S., Lickley, L., Kovacevic, N., and Vranic, M. 1987. Elevated somatostatin in pancreatic islets of adrenalectomized dogs. Endocrinology (Baltimore), 120: 544-548.

Rastogi, K.S., Lickley, L., Jokay, M., Efendic, S., and Vranic, M. 1990. Paradoxical reduction in pancreatic glucagon with normalization of somatostatin and decrease in insulin in normoglycemic alloxan diabetic dogs: a putative mechanism of glucagon irresponsiveness to hypoglycemia. Endocrinology (Baltimore), 126: 10961104.

Rastogi, K.S., Kawasaki, A., Efendic, S., Brubaker, P.L., and Vranic, M. 1991. Increase in somatostatin to glucagon ratio in alloxan diabetic dogs: a potential mechanism for glucagons irresponsiveness to hypoglycemia. Program of the 73rd Annual Meeting of The Endocrine Society, Washington, D.C. The Endocrine Society 1991. p. 476.

Roberge, J.N., and Brubaker, P.L. 1991. Secretion of proglucagonderived peptides in response to intestinal luminal nutrients. Endocrinology (Baltimore), 128: 3169-3174.

Ruggere, M.D., and Patel, Y.C. 1984. Somatostatin, glucagon and insulin secretion from perfused pancreas of BB rats. Am. J. Physiol. 247: E221-E227.

Schusdziara, V., Dobbs, R.E., Harris, V., and Unger, R.H. 1977. Immunoreactive somatostatin levels in plasma of normal and alloxan diabetic dogs. FEBS Lett. 81: 69-72.

Schusdziara, V., Pouiller, V.H., Conlon, J.M., and Unger, R.H. 1978. The response of plasma somatostatin-like immunoreactivity to nutrients in normal and alloxan diabetic dogs. Endocrinology (Baltimore), 103: 2264-2273.

Soejima, K., and Landing, B.H. 1986. Pancreatic islets in older patients with cystic fibrosis with and without diabetes mellitus. Ped. Pathol. 6: 25-46.

Stefan, Y., Orci, L., and Malaisse-Lagae, F. 1982. Quantitation of endocrine cell content in the pancreas of non-diabetic and diabetic human. Diabetes, 31: 694-700.

Sternberger, L.A. 1979. The unlabelled antibody peroxidaseantiperoxidase (PAP) method. In Immunocytochemistry. John Wiley \& Sons, New York. pp. 104-130.

Unger, R.H., and Orci, L. 1977. Role of glucagon in diabetes. Arch. Intern. Med. 137: 482-491.

van Schravendijk, C.H.F., Foriers, A., Hooghe-Peters, E.L., Rogiers, V., De Meyts, P., Sodoyez, J.C., and Pipeleers, D.G. 1985. Pancreatic hormone receptors on islet cells. Endocrinology (Baltimore), 117: 841-848. 